\title{
Effects of Residual Organic Manure and Supplemental Inorganic Fertilizers on Performance of Subsequent Maize Crop and Soil Chemical Properties
}

\author{
Almaz M. Gezahegn Halim, R.A Martini, M. Y. \\ Faculty of Agriculture, Universiti Putra Malaysia, 43400 Serdang, Selangor, Malaysia \\ ${ }^{1}$ Ethiopian Institute of Agricultural Research, Addis Abeba, Ethiopa
}

\begin{abstract}
Field experiments were conducted during 2014 and 2015 to evaluate the effects of residual organic fertilizers with supplemental inorganic fertilizers on performance of subsequent maize crop and soil chemical properties at Field 2, Faculty of Agriculture, Universiti Putra Malaysia, Serdang, Selangor, Malaysia. In the first season, the trial was conducted by using 4 nutrient management treatment (control, $100 \%$ poultry manure (PM), 100\% NPK and $50 \%$ $\mathrm{NPK}+50 \% \mathrm{PM}$ ) in 3 cropping system (sole maize, sole soybean and maize + soybean intercropping). The following trial was conducted by using the first experimental plot. After harvest of the crops in the first experiment, the biomass was left and incorporated manually into the soil before planting the subsequent maize crop. The experiment comprised of 14 treatments, 12 based on the first experiment and two additional treatments for comparison (control and 100\% NPK). The treatments were laid down in a randomized complete block design (RCBD) with three replications. The results showed that all fertilizer treatments increased growth, yield and yield components of the subsequent maize crop. However, incorporation of maize residue alone was ineffective in increasing yield of the subsequent maize crop. The combination of crop residue with residual PM enhanced soil $\mathrm{pH}$, organic matter and nutrient availability in the soil. The combined application of soybean residue $+50 \%$ residual $\mathrm{PM}+50 \%$ phosphorous and potassium (PK) fertilizer and soybean residue $+100 \%$ PK gave maize yield same level as $100 \%$ NPK. Therefore, it can be recommended that substitution of $50 \%$ inorganic fertilizer with residual $\mathrm{PM}$ and substitution of $\mathrm{N}$ fertilizer in soybean residue is recommended to increase yield of maize and improve soil chemical properties.
\end{abstract}

Keywords: crop residue, NPK fertilizer, poultry manure, residue, yield

DOI: $10.7176 /$ JNSR/9-22-05

Publication date: November $30^{\text {th }} 2019$

\section{INTRODUCTION}

Currently, the emphasis has been shifted from individual crop to cropping system as a whole since the responses of the component crop in the cropping system are influenced by the previous crops and the applied inputs (Silva et al., 2006). The available nutrients in organic manure are not fully accessible to the crops in the current season (Rosen \& Bierman, 2005). Organic manure, besides providing nutrients to the existing crop, usually leaves a considerable residual nutrient on the subsequent crops in the cropping system. The residual effect of organic manure applied to the soil refers to the carry-over effect of the application on the subsequent crop (Silva et al., 2006). Decomposition of organic manure and the release of nutrients are more gradual and stored for a longer period in the soil, thus ensuring longer residual effect and improved crop yields (Paul \& Beauchamp, 1994). Similarly, incorporation of crop residues in agricultural soils is primarily a means to maintain soil organic matter which results in enhanced biological activity, physical properties and nutrient availability (Antil \& Narwal, 2007). The most immediate effect of residue application is on the availability of nitrogen to the succeeding crop as a result of mineralization-immobilization processes (Hadas et al., 2004). Crop residues, mainly leguminous residues, have a great nitrogen benefit and reduce the need for mineral $\mathrm{N}$ fertilizer application by smallholder farmers and widen their gross benefit in maize production (Svubure et al., 2010).

Maize (Zea mays $L$ ) is one of the important cereal crops in the world next to wheat and rice. Maize serves as a staple food for over 900 million people in the developing countries, and it is the most dependable crop to bring about food self-reliance and independence (Zerihun et al., 2013). Maize is a high yield potential, which needs balanced use of organic manures and inorganic fertilizers to produce desired yield. Integrated use of organic residues and inorganic fertilizers can sustain soil fertility and soil organic matter required for sustainable high yields and maximum benefits for smallholder farming in the tropics (Shahzad et al., 2015; Vanlauwe et al., 2010). Keeping the above points in view, the present investigation was undertaken with the objective of determining the residual effect of poultry manure applied to the previous crop with incorporation of crop residue with and without supplemental inorganic fertilizers on yield, of succeeding maize crop and soil chemical properties.

\section{Materials and Methods}

An experiment was conducted in 2014 and 2015 at Field 2, Faculty of Agriculture, Universiti Putra Malaysia 
(UPM) Serdang, Selangor, Malaysia. The site is located at altitude of 3: 02' N, a longitude of 101: 42' E and an altitude of $31 \mathrm{~m}$ above sea level. Total annual rainfall was $2689 \mathrm{~mm}$ with a monthly average of $224 \mathrm{~mm}$. The minimum and maximum average temperatures were $25.06{ }^{\circ} \mathrm{C}$ and $32.66{ }^{\circ} \mathrm{C}$, respectively. The soil type of experimental site was classified as Bungor series (Typic Paleudult). Data on initial physical and chemical properties of soil at experimental site are presented in Table 1.

In the first season, the trial was conducted by using 4 nutrient management treatment (control, 100\% poultry manure (PM), 100\% NPK and 50\% NPK $+50 \% \mathrm{PM}$ ) in 3 cropping system (sole maize, sole soybean and maize + soybean intercropping). The following experiment was conducted by using the first experimental plot. After harvest crops of the first experiment, the biomass was left and incorporated manually into the soil before planting the subsequent maize crop. The experiment comprises of 14 treatments as shown in Table 2. Treatments 1-4 were from plots of the previous maize crop where the treatments were no fertilizer, $100 \%$ NPK fertilizer, $100 \%$ PM and $50 \%$ NPK $+50 \%$ PM, respectively. Treatments 5-8 were from plots of the previous soybean crop where the treatments were no fertilizer, 100\% NPK fertilizer, 100\% PM and 50\% NPK $+50 \%$ PM, respectively. Treatments $8-12$ were from plots of the previous maize + soybean intercropping where the treatments were no fertilizer, $100 \%$ NPK fertilizer, 100\% PM and 50\% NPK $+50 \%$ PM, respectively. Treatments 11 and 12 are additional plots which were not fertilized (control) and applied with 100\% NPK, respectively. The treatments were laid down in randomized complete block design $(\mathrm{RCBD})$ with three replications.

\section{Land preparation, planting, field management and harvesting}

After harvest of the planted crops in the first experiment, the biomasses of the crops were weighed and left on the plots. The residues were weighed, chopped $(10-15 \mathrm{~cm})$ and manually incorporated in the top $0-30 \mathrm{~cm}$ using hoes. The application rates of the residue were depending on the biomass produced in the respective plots. The nutrient composition of the residue was analyzed in the laboratory before application (Table 2). The amount of $\mathrm{N}_{2} \mathrm{P}_{2} \mathrm{O}_{5}: \mathrm{K}_{2} \mathrm{O}$ for 100\% NPK treatment were, 120:80:60, respectively, and $\mathrm{P}_{2} \mathrm{O}_{5}: \mathrm{K}_{2} \mathrm{O}$ for $100 \% \mathrm{PK}$ fertilizer were, $80: 60 \mathrm{~kg} / \mathrm{ha}$, respectively.

The first trial was planted on May 20, 2014 and harvested on August 5, 2014. Whereas, the crop in the second season was planted on October 5, 2014 and harvested on January 5, 2015.

The amount of PM in the first season was calculated based on $\mathrm{N}$ equivalence $\left(120\right.$ and $20 \mathrm{~kg} \mathrm{ha}^{-1}$ for maize and soybean, respectively) and applied on dry weight basis two weeks prior to planting. The amount of PM in sole maize, sole soybean and intercropping plot were $3 \mathrm{t} \mathrm{ha}^{-1}, 0.4 \mathrm{t} \mathrm{ha}^{-1}$ and $2 \mathrm{t} \mathrm{ha}^{-1}$, respectively. The chemical composition of PM is presented in Table 3. The amount of $\mathrm{N}: \mathrm{P}_{2} \mathrm{O}_{5}: \mathrm{K}_{2} \mathrm{O}$ for $100 \%$ NPK treatment were 120:80:60 and 20:80:60 $\mathrm{kg} \mathrm{ha}^{-1}$ for maize and soybean, respectively. The application rate of NPK for both crops was based on the result of the initial soil analysis and the nutrient requirement for the crops (Table 1 and 4$)$. Urea (46\% N), triple super phosphate (TSP) $\left(46 \% \mathrm{P}_{2} \mathrm{O}_{5}\right)$ and Muriate of potash (MOP) $\left(46 \% \mathrm{~K}_{2} \mathrm{O}\right)$ were used as the source of $\mathrm{N}$, $\mathrm{P}$ and $\mathrm{K}$ respectively. The full dose of $\mathrm{P}$ and $\mathrm{K}$ and one-third of $\mathrm{N}$ fertilizer were applied at the sowing time. The remaining two- third of $\mathrm{N}$ fertilizer was added at 8-leaf stage of maize as a topdressing while for soybean plots full dose of N, P and $\mathrm{K}$ were applied at planting. Other agronomic practices were kept uniform for all treatments.

Measured variables taken were include plant height, cob length, number of kernels per cob, 1000 kernel weight, green cob weight, marketable cobs/ha, green cob yield $(\mathrm{kg} / \mathrm{ha})$, biomass yield $(\mathrm{kg} / \mathrm{ha})$ and harvest index (HI).

\section{Soil sampling and analysis}

Composite initial soil samples at a depth of 0-30 cm were taken from ten random spots within the experimental site prior to treatment application and after harvest from each plot. The composite samples were air-dried, sieved to pass through a $2 \mathrm{~mm}$ mesh and analyzed for selected physico-chemical properties, including texture (percentage of sand, silt, and clay), $\mathrm{pH}$, total nitrogen, organic matter content, available phosphorus, exchangeable $\mathrm{K}$ and cation exchange capacity (CEC). The soil organic carbon content, total nitrogen and sulfur were determined by dry combustion with CHNS LECO analyzer (Jimenez \& Ladha, 1993). Soil pH was determined using the glass electrode $\mathrm{pH}$ meter in a 1:2.5 soil to water ratio (Van Reeuwijk, 1992), and cation exchange capacity was measured by ammonium acetate method $\left(\mathrm{NH}_{4} \mathrm{OAC}\right)$ by saturating the soil with $1 \mathrm{~N} \mathrm{NH}_{4} \mathrm{OAC}$ and displacing it with $1 \mathrm{~N}$ $\mathrm{K}_{2} \mathrm{SO}_{4}$ (Chapman, 1965). Exchangeable $\mathrm{K}$ was extracted with $1 \mathrm{~N} \mathrm{NH}_{4} \mathrm{OAc}$ at $\mathrm{pH} 7$ and the extract was analysed using an Atomic Absorption Spectrophotometer (Perkin-Elmer, Massachusetts, USA). Available phosphorus was determined by the Bray-II method (Bray and Kurtz, 1945) and determined by an Auto-Analyzer (Lachat instrument, WI, USA). Soil texture was determined by the pipette method (Day, 1965). The texture class was determined using the United States Department of Agriculture (USDA) soil textural triangle.

\section{Statistical analysis}

The data collected were subjected to statistical analysis appropriate to RCBD. Analyses of variance (ANOVA) were carried out using SAS (Version 9.4) Statistical Software Package. Duncan's Multiple Range Test (DMRT) 
was used to compare treatment means at $0.05 \%$ probability levels. Pearson correlation was conducted to determine the relationship among the variables taken.

\section{Result and Discussion}

Treatments applied had a significant effect on growth and yield characteristics of maize (Table 4). The highest plant height $(203,204$ and $203 \mathrm{~cm})$, cob length $(34.8,37.2$ and $37.8 \mathrm{~cm})$, number of kernels per cob $(519,509$ and 520), 1000 kernel weight (684, 683 and $694 \mathrm{~g})$ and green cob weight (560, 550 and $533 \mathrm{~g})$ were obtained from application of $100 \% \mathrm{NPK}$, combined application of soybean residue $+100 \%$ PK and soybean residue $+50 \%$ residual PM $+50 \%$ PK, respectively. In contrast, the lowest plant height $(94$ and $105 \mathrm{~cm})$, cob length $(20.6$ and $20.8 \mathrm{~cm}), 1000$ kernel weight (283 and $318 \mathrm{~g}$ ), number of kernels per cob (286 and $286 \mathrm{~g}$ ) and green cob weight (200 and $208 \mathrm{~g}$ ) were obtained from control and the application of sole maize residue. Improvement in physical and chemical properties of soil treated with crop residue, residual PM, and inorganic fertilizers resulted in better growth. Maize growth in the combination of soybean residue, residual PM and PK fertilizer was comparable with sole application of NPK fertilizer. This shows that maize performed very well without addition of any inorganic $\mathrm{N}$ fertilizer if soybean residues and PM are applied. This might be due to the better availability of soil N possibly resulting from the decomposition of the incorporated soybean residue and residual PM. In addition, the highest plant height $(203 \mathrm{~cm})$ of the maize under $100 \%$ NPK was due to the fact that nutrients released early from the inorganic fertilizer and maize being a destructive feeder could use it for its growth. A similar finding was reported by Kravchenko and Thelen (2007) who indicated that addition of crop residues improved plant growth, relative chlorophyll content and plant height of corn.

Effects of organic manure residues and inorganic fertilizer on yield characteristics of maize is presented in Table 5. Treatments applied had a significant effect on yield characteristics of maize. Sole application of $100 \%$ NPK, combined application of soybean residue $+100 \%$ PK, and soybean residue $+50 \%$ residual PM $+50 \%$ PK fertilizer gave highest marketable cob $(61,045,61,867$ and 62,517 , respectively), green cob yield $(37,290,36,500$ and $37,010 \mathrm{~kg} / \mathrm{ha}$, respectively), biomass yield (47,545, 44,550 and 45,873 kg/ha, respectively), and harvest index (78, 82 and 81\%, respectively). The increase in green cob and biomass yield under combined application of soybean residue along with the residual PM and PK fertilizer soybean residue + PK fertilizer and sole application of NPK were the reflections of improved plant growth and yield components of the crop. In these treatments, greater growth and leaf area might have increased the photosynthetic activity, which contributed to higher accumulation of carbohydrates. The relatively higher amount of carbohydrate could have promoted the growth rate and, thus increased the yield. This might be due to integrated application of organic and inorganic fertilizers may increase residue decomposition and plant use efficiency of nutrients from both organic manure and inorganic fertilizer. The result is in agreement with Gitari and Friesen (2002) and Ayoola and Makinde (2007) who reported the maximum yield in a combination of organic and inorganic fertilizer. Akintoye and Olaniyan (2012) also found higher green cob yields of sweet corn from the application of $\mathrm{N}, \mathrm{P}$ and $\mathrm{K}$ fertilizer.

The increased yield in combined application of soybean residue + PK fertilizer $(36,500 \mathrm{~kg} / \mathrm{ha})$ and soybean residue $+50 \%$ residual PM $+50 \%$ PK fertilizer $(37,010 \mathrm{~kg} / \mathrm{ha})$ as the same level as $100 \%$ NPK fertilizer $(37,290$ $\mathrm{kg} / \mathrm{ha}$ ) shows that maize yield can be sustained without the addition of any inorganic $\mathrm{N}$ fertilizer if soybean residues and PM are applied. This was probably due to higher $\mathrm{N}$ availability caused by greater mineralization of $\mathrm{N}$ from soybean residue and PM. This might increase the $\mathrm{N}$ uptake and therefore increased the photosynthesis rate and subsequently photosynthetic partitioning towards the developing grain. This result is consistent with Khan et al. (2008) who reported that returning of soybean residue without applying $\mathrm{N}$ fertilizer increased the subsequent wheat yield by $44.9 \%$. Similarly, Aulakh (2010) reported higher yields, N and P uptake and nutrient use-efficiency in the incorporation of groundnut crop residues in combination with inorganic fertilizers.

\section{Correlation of various maize traits with green cob yield as affected by organic and inorganic fertilizer}

Correlation of green cob yield with yield components are presented in Table 6 . There was a significant $(\mathrm{P}<0.0001)$ positive correlation between green cob yield and plant height $\left(R^{2}=0.95\right)$, cob length $\left(R^{2}=0.94\right)$, green cob weight $\left(\mathrm{R}^{2}=0.99\right)$, number of kernels per cob $\left(\mathrm{R}^{2}=0.97\right)$, thousands kernel weight $\left(\mathrm{R}^{2}=0.99\right)$, biological yield $\left(\mathrm{R}^{2}=\right.$ $0.99)$ and harvest index $\left(\mathrm{R}^{2}=0.98\right)$, LAI $\left(\mathrm{R}^{2}=0.88\right)$, CGR $\left(\mathrm{R}^{2}=0.96\right)$, relative chlorophyll content $\left(\mathrm{R}^{2}=0.93\right)$.

\section{Soil chemical properties}

Implemented treatments had a significant effect on all measured soil chemical properties (Table 7). The results revealed an increase in soil chemical properties due to the sole and combined application of organic residue. The increase in soil $\mathrm{pH}$ due to the incorporation of crop residues and residual poultry manure was attributed to increased microbial activity during the process of decomposition and organic matter formation. The decomposition of organic matter resulted in the release of more exchangeable bases such as $\mathrm{K}, \mathrm{Ca}$, and $\mathrm{Mg}$ that reduce the soil acidity near to neutrality. The result is in agreement with the study done in different parts of tropics (Lee et al., 2006) where the application of organic materials such as crop residues, green manure, and compost improved soil $\mathrm{pH}$, 
available nutrients, organic matter content, and reduced exchangeable acidity. Hue (1992) also reported an increase in soil $\mathrm{pH}$ after incorporation of crop residue due to the release of $\mathrm{NH}_{3}$ from decomposing organic materials and the production of $\mathrm{OH}^{-}$ions.

The increase in organic matter attributed to the direct addition of organic matter through crop residue and PM and as a result of decomposition. This is because organic matter is the major product of decomposition (Ogbodo, 2011). The result is supported by Mungai and Motavalli (2006) who reported that incorporation of a mixture of cereal and legume residue significantly increased the maintenance of soil organic $\mathrm{C}$ and $\mathrm{N}$. The slow decomposing residues have a steady impact on soil structure and provide a long-term impact on increasing levels of soil organic matter (Cattaneo et al., 2014).

Organic materials enhance the nutrient availability of the soil through a gradual release of nutrients and lessening of nutrient losses. The availability of soil N, P and $\mathrm{K}$ in the soil were improved by the addition of different crop residue and residual poultry manure. The increase in total soil nitrogen when soybean residue was incorporated alone or in combination with maize was due to the ability of legume to fix atmospheric $\mathrm{N}$ in the soil. Similarly, Crookston et al. (1991) and Meese et al. (1991) reported that the soybean $\mathrm{N}$ credit varies by cropping season, yield of the previous soybean crop and soil organic matter content. Hadas et al. (2004) also reported a significant effect of using organic amendments on $\mathrm{N}$ availability to the following crop due to their mineralization. The organic materials can likewise diminish P fixation by covering the fixation site on the soil colloids and by creating chelates with $\mathrm{Al}, \mathrm{Fe}$, and $\mathrm{Mn}$ particles, therefore increase the $\mathrm{P}$ availability. Similar results were reported by Babhulkar et al. (2000) . In addition, the release of organic acid during microbial decomposition of organic matter which might have facilitated the solubility of native phosphates by hindering of P-sorption sites (Diack et al., 2000).

The increment in the available $\mathrm{K}$ content in treatments with residual poultry manures was due to the beneficial effects of poultry manures in releasing $\mathrm{K}_{2} \mathrm{O}$ during decomposition and the direct addition of $\mathrm{K}_{2} \mathrm{O}$ to the available pool of the soil. In addition, soybean and maize residue are very rich in $\mathrm{K}$ which added more $\mathrm{K}$ to the soil. The increase in soil organic matter could improve soil $\mathrm{K}$ availability and CEC since soil organic matter comprises of cation exchange sites that preserve exchangeable K (Johnston et al., 2009). Similar beneficial effect of FYM and crop residue on the available K content of the soil was reported by Mathan and Mahendran (1994) and Surekha et al. (2003), respectively. Similarly, Mbah and Nneji (2011) reported that retention of crop residue significantly increased exchangeable bases and CEC of the soil compared to the control. In contrast, Rosenani et al. (2003) reported no significant effect of maize and groundnut crop residue on soil CEC in the first year of application. Integrated nutrient management by the use of organic manures is practiced to maintain fertility status of the soil thereby enhanced crop productivity. It also benefits to sustain the productive of the cropping systems. These findings are supported by Marimuthu et al. (2014) who concluded that crop productivity and soil fertility status can be sustained with integrated plant nutrient management practices. Ali et al. (2009) also reported that the combination of crop residue, organic manure and inorganic fertilizer to rice cropping system improved soil organic carbon and NPK contents compared to control.

\section{Conclusions}

Based on the results, sole and combined application of crop residue, inorganic fertilizer, and residual PM gave significantly higher growth, yield and yield component of maize than that of the control. The incorporation of soybean residue or maize + soybean residue from the previous crop managed to increase maize yield without additional $\mathrm{N}$ fertilizer. On the other hand, incorporation of maize residue alone gave no increase in yield over the control. Among the treatments applied, the combined application of soybean residue $+100 \%$ PK and soybean residue + residue of $50 \% \mathrm{PM}+50 \% \mathrm{PK}$ increased maize yield to the same level as $100 \% \mathrm{NPK}$ fertilizer. In addition, residual PM and crop residue from the previous crop can improve soil nutrient and soil organic matter. Organic residues, such as crop residue and poultry manure are cheap and easily available sources of nutrients for smallholder farmers compared to expensive inorganic fertilizer and also they are environmentally friendly. Therefore, substitution of $\mathrm{N}$ fertilizer with soybean residue and substitution of $50 \%$ NPK fertilizer with PM is recommended to increase yield of maize and improve soil fertility.

\section{References}

Akintoye, H., \& Olaniyan, A. (2012). Yield of sweet corn in response to fertilizer sources. Global Advanced Research Journal of Agricultural Science, 1(5), 110-116.

Antil, R., \& Narwal, R. (2007). Integrated nutrient management for sustainable soil health and crop productivity. Indian Journal of Fertilizers, 3(9), 111.

Aulakh, M. (2010). Integrated nutrient management for sustainable crop production, improving crop quality and soil health, and minimizing environmental pollution. Paper presented at the 19th World Congress of Soil Science, Soil Solutions for a Changing World, Brisbane.

Ali, M., Islam, M., \& Jahiruddin, M. (2009). Effect of integrated use of organic manures with chemical fertilizers 
in the rice-rice cropping system and its impact on soil health. Bangladesh Journal of Agricultural Research, 34(1), 81-90.

Ayoola, O., \& Makinde, E. (2007). Fertilizer treatment effects on performance of cassava under two planting patterns in a cassava-based cropping system in South West Nigeria. Research Journal of Agriculture and Biological Sciences, 3(1), 13-20.

Babhulkar, P., Wandile, R., Badole, W., \& Balpande, S. (2000). Residual effect of long-term application of FYM and fertilizers on soil properties (Vertisols) and yield of soybean. Journal of the Indian Society of Soil Science, 48(1), 89-92.

Bray, R. H., \& Kurtz, L. (1945). Determination of total, organic, and available forms of phosphorus in soils. Soil Science, 59(1), 39-46.

Cattaneo, F., Barbanti, L., Gioacchini, P., Ciavatta, C., \& Marzadori, C. (2014). 13C abundance shows effective soil carbon sequestration in miscanthus and giant reed compared to arable crops under Mediterranean climate. Biology and Fertility of Soils, 50(7), 1121-1128.

Chapman, S. (1997). Carbon substrate mineralization and sulphur limitation. Soil Biology and Biochemistry, 29(2), $115-122$.

Crookston, R., Kurle, J., Copeland, P., Ford, J., \& Lueschen, W. (1991). Rotational cropping sequence affects yield of corn and soybean. Agronomy Journal, 83(1), 108-113.

Day, P. R. (1965). Particle fractionation and particle-size analysis (No. methodsofsoilana, pp. 545-567). American Society of Agronomy, Soil Science Society of America.

Diack, M., Sene, M., Badiane, A., Diatta, M., \& Dick, R. (2000). Decomposition of a native shrub, Piliostigma reticulatum, litter in soils of semiarid Senegal. Arid Soil Research and Rehabilitation, 14(3), 205-218.

Gitari, J., \& Friesen, D. (2002). The use of organic/inorganic soil amendments for enhanced maize production in the central highlands of Kenya. Integrated Approaches to Higher Maize Productivity in the New Millennium. Embu, Kenya.

Hadas, A., Kautsky, L., Goek, M., \& Kara, E. E. (2004). Rates of decomposition of plant residues and available nitrogen in soil, related to residue composition through simulation of carbon and nitrogen turnover. Soil Biology and Biochemistry, 36(2), 255-266.

Hue, N. (1992). Correcting soil acidity of a highly weathered Ultisol with chicken manure and sewage sludge. Communications in Soil Science \& Plant Analysis, 23(3-4), 241-264.

Jimenez, R., \& Ladha, J. (1993). Automated elemental analysis: a rapid and reliable but expensive measurement of total carbon and nitrogen in plant and soil samples. Communications in Soil Science \& Plant Analysis, 24(15-16), 1897-1924.

Johnston, A. E., Poulton, P. R., \& Coleman, K. (2009). Soil organic matter: its importance in sustainable agriculture and carbon dioxide fluxes. Advances in Agronomy, 101, 1-57.

Khan, A., Jan, M. T., Arif, M., Marwat, K. B., \& Jan, A. (2008). Phenology and crop stand of wheat as affected by nitrogen sources and tillage systems. Pakistan Journal of Botany, 40(3), 1103-1112.

Kravchenko, A. G., \& Thelen, K. D. (2007). Effect of winter wheat crop residue on no-till corn growth and development. Agronomy Journal, 99(2), 549-555.

Lee, C. H., Wu, M.-Y., Asio, V. B., \& Chen, Z. S. (2006). Using a soil quality index to assess the effects of applying swine manure compost on soil quality under a crop rotation system in Taiwan. Soil Science, 171(3), 210-222.

Mathan, K., \& Mahendran, P. (1994). Infiltration characteristics of soils as related to soil physical properties. Journal of the Indian Society of Soil Science, 42(3), 441-444.

Marimuthu, S., Surendran, U., \& Subbian, P. (2014). Productivity, nutrient uptake and post-harvest soil fertility as influenced by cotton-based cropping system with integrated nutrient management practices in semi-arid tropics. Archives of Agronomy and Soil Science, 60(1), 87-101.

Mbah, C., \& Nneji, R. (2011). Effect of different crop residue management techniques on selected soil properties and grain production of maize. African Journal of Agricultural Research, 6(17), 4149-4152.

Meese, B., Carter, P., Oplinger, E., \& Pendleton, J. (1991). Corn/soybean rotation effect as influenced by tillage, nitrogen, and hybrid/cultivar. Journal of Production Agriculture, 4(1), 74-80.

Mungai, N. W., \& Motavalli, P. P. (2006). Litter quality effects on soil carbon and nitrogen dynamics in temperate alley cropping systems. Applied Soil Ecology, 31(1), 32-42.

Ogbodo, E. (2011). Effect of crop residue on soil chemical properties and rice yield on an Ultisol at Abakaliki, Southeastern Nigeria. World Journal of Agricultural Sciences, 7(1), 13-18.

Paul, J., \& Beauchamp, E. (1994). Short-term nitrogen dynamics in soil amended with fresh and composted cattle manures. Canadian Journal of Soil Science, 74(2), 147-155.

Rosen, C. J., \& Bierman, P. M. (2005). Using manure and compost as nutrient sources for fruit and vegetable crops. In U. O. M. Extension (Ed.), Commercial fruit and vegetable production. Minnesota.

Rosenani, A., Mubarak, A., \& Zauyah, S. (2003). Recycling of crop residues for sustainable crop production in a 
maize-groundnut rotation system. Management of Crop Residues for Sustainable Crop Production, 3.

Shahzad, K., Khan, A., Smith, J. U., Saeed, M., Khan, S., \& Khan, S. (2015). Residual effects of different tillage systems, bioslurry and poultry manure on soil properties and subsequent wheat productivity under humid subtropical conditions of Pakistan. International Journal of Biosciences (IJB), 6(11), 99-108.

Silva, J. d., de Oliveira, F. H. T., de Sousa, A. K. F., \& Duda, G. P. (2006). Residual effect of cattle manure application on green ear yield and corn grain yield. Horticultura Brasileira, 24(2), 166-169.

Surekha, K., Kumari, A. P., Reddy, M. N., Satyanarayana, K., \& Cruz, P. S. (2003). Crop residue management to sustain soil fertility and irrigated rice yields. Nutrient Cycling in Agroecosystems, 67(2), 145-154.

Svubure, O., Mpepereki, S., \& Makonese, F. (2010). Sustainability of maize-based cropping systems in rural areas of Zimbabwe: an assessment of the residual soil fertility effects of grain legumes on maize (Zea mays [L.]) under field conditions. International Journal of Engineering, Science and Technology, 2(7), 141-148.

Vanlauwe, B., Bationo, A., Chianu, J., Giller, K. E., Merckx, R., Mokwunye, U., et al. (2010). Integrated soil fertility management operational definition and consequences for implementation and dissemination. Outlook on Agriculture, 39(1), 17-24.

Van Reeuwijk, L. P. (1992). Procedures for soil analysis, 3rd Ed. International Soil Reference and Information Center (ISRIC). Wageningen, the Netherlands.

Zerihun, A., Sharma, J., Nigussie, D., \& Fred, K. (2013). The effect of integrated organic and inorganic fertilizer rates on performances of soybean and maize component crops of a soybean/maize mixture at Bako, Western Ethiopia. African Journal of Agricultural Research, 8(29), 3921-3929.

Table 1: Initial physical and chemical properties of experimental soil $(n=3)$

\begin{tabular}{ll}
\hline Soil Properties & Value \\
\hline pH & $5.62 \pm 0.19$ \\
Total N (\%) & $0.08 \pm 0.01$ \\
Available P (mg/kg) & $16.0 \pm 1.95$ \\
Exchangeable K (cmolc/kg) & $0.33 \pm 0.12$ \\
S (mg/kg) & $49.6 \pm 17.18$ \\
CEC (cmolc/kg) & $14.5 \pm 0.37$ \\
OM (\%) & $2.2 \pm 0.32$ \\
Texture & Sandy loam \\
Clay (\%) & 18.98 \\
Sand (\%) & 65.73 \\
Silt (\%) & 15.25 \\
\hline
\end{tabular}

Table 2: Treatment combinations

\begin{tabular}{ll}
\hline Treatment no. & Description \\
\hline $\mathbf{1}$ & Maize residue (MR) \\
$\mathbf{2}$ & Maize residue $+100 \% \mathrm{PK}$ \\
$\mathbf{3}$ & Maize residue + residual $50 \% \mathrm{PM}+50 \% \mathrm{PK}$ \\
$\mathbf{4}$ & Maize residue + residual $100 \% \mathrm{PM}$ \\
$\mathbf{5}$ & Soybean residue \\
$\mathbf{6}$ & Soybean residue $+100 \% \mathrm{PK}$ \\
$\mathbf{7}$ & Soybean residue + residual $50 \% \mathrm{PM}+50 \% \mathrm{PK}$ \\
$\mathbf{8}$ & Soybean residue + residual $100 \% \mathrm{PM}$ \\
$\mathbf{9}$ & Maize + soybean residue \\
$\mathbf{1 0}$ & Maize + soybean residue $+100 \% \mathrm{PK}$ \\
$\mathbf{1 1}$ & Maize + soybean residue + residual $50 \% \mathrm{PM}+50 \% \mathrm{PK}$ \\
$\mathbf{1 2}$ & Maize + soybean residue + residual $100 \% \mathrm{PM}$ \\
$\mathbf{1 3}$ & Control (no fertilizer and no residue) \\
$\mathbf{1 4}$ & $100 \%$ NPK \\
\hline
\end{tabular}


Table 3: Chemical composition of poultry manure

\begin{tabular}{ll}
\hline Nutrient Element & Values (\%) \\
\hline $\mathbf{N}$ & 4.50 \\
$\mathbf{P}$ & 1.08 \\
$\mathbf{K}$ & 1.66 \\
$\mathbf{C a}$ & 1.43 \\
$\mathbf{M g}$ & 0.60 \\
$\mathbf{p H}$ & 7.10 \\
\hline
\end{tabular}

Table 4. Effects of organic manure residues and inorganic fertilizer on agronomic and yield traits of maize

\begin{tabular}{llllll}
\hline Treatment & PH $(\mathbf{c m})$ & CL $(\mathbf{c m})$ & NK/C & TKW (g) & GCW (g) \\
\hline Control & $94 \mathrm{~g}$ & $20.6 \mathrm{e}$ & $283 \mathrm{f}$ & $286 \mathrm{~h}$ & $200 \mathrm{~g}$ \\
$\mathbf{1 0 0 \%}$ NPK & $203 \mathrm{a}$ & $34.8 \mathrm{a}$ & $684 \mathrm{a}$ & $519 \mathrm{a}$ & $560 \mathrm{a}$ \\
MR & $105 \mathrm{f}$ & $20.8 \mathrm{e}$ & $318 \mathrm{ef}$ & $286 \mathrm{~h}$ & $208 \mathrm{~g}$ \\
MR + 100\% PK & $162 \mathrm{~d}$ & $23.3 \mathrm{de}$ & $389 \mathrm{~d}$ & $325 \mathrm{gh}$ & $308 \mathrm{e}$ \\
MR + 100\% RPM & $163 \mathrm{~d}$ & $22.7 \mathrm{e}$ & $423 \mathrm{~d}$ & $339 \mathrm{efg}$ & $350 \mathrm{~cd}$ \\
MR + 50\% RPM + 50\% PK & $167 \mathrm{~d}$ & $27.8 \mathrm{bc}$ & $484 \mathrm{c}$ & $387 \mathrm{cde}$ & $378 \mathrm{c}$ \\
SR & $166 \mathrm{~d}$ & $25 \mathrm{~cd}$ & $409 \mathrm{~d}$ & $353 \mathrm{def}$ & $325 \mathrm{de}$ \\
SR+ 100\% PK & $204 \mathrm{a}$ & $37.2 \mathrm{a}$ & $683 \mathrm{a}$ & $509 \mathrm{a}$ & $550 \mathrm{a}$ \\
SR + 100\% RPM & $189 \mathrm{~b}$ & $30.8 \mathrm{~b}$ & $539 \mathrm{bc}$ & $431 \mathrm{bc}$ & $445 \mathrm{~b}$ \\
SR + 50\% RPM + 50\% PK & $203 \mathrm{a}$ & $37.8 \mathrm{a}$ & $694 \mathrm{a}$ & $520 \mathrm{a}$ & $533 \mathrm{a}$ \\
MSR & $118 \mathrm{e}$ & $22.5 \mathrm{de}$ & $369 \mathrm{de}$ & $302 \mathrm{gh}$ & $259 \mathrm{f}$ \\
MSR + 100\% PK & $177 \mathrm{c}$ & $28.5 \mathrm{bc}$ & $551 \mathrm{~b}$ & $408 \mathrm{bc}$ & $432 \mathrm{~b}$ \\
MSR + 100 \% RPM & $178 \mathrm{c}$ & $27.8 \mathrm{bc}$ & $489 \mathrm{c}$ & $400 \mathrm{bcd}$ & $376 \mathrm{c}$ \\
MSR + 50\% RPM + 50\% PK & $178 \mathrm{c}$ & $29.8 \mathrm{~b}$ & $573 \mathrm{~b}$ & $442 \mathrm{~b}$ & $433 \mathrm{~b}$ \\
\hline
\end{tabular}

Means in the same column followed by the same letters are not significantly different (DMRT 0.05 ), $\mathrm{PH}=\mathrm{plant}$ height, $\mathrm{CL}=$ cob length, $\mathrm{GCW}=$ green cob weight, $\mathrm{NK} / \mathrm{C}=$ number of kernels per cob, $\mathrm{TKW}=$ thousand kernel weight, $\mathrm{MR}=$ maize residue, $\mathrm{SR}=$ soybean residue, $\mathrm{MSR}=$ maize + soybean residue, $\mathrm{RPM}=$ residual poultry manure, $\mathrm{PM}=$ poultry manure, $\mathrm{PK}=$ phosphorus and potassium fertilizer

Table 5. Effects of organic manure residues and inorganic fertilizer on yield characteristics of maize

\begin{tabular}{lllll}
\hline Treatment & MC/ha (no.) & GCY (kg/ha) & BY (kg/ha) & HI (\%) \\
\hline Control & $31,437 \mathrm{e}$ & $10,323 \mathrm{~h}$ & $18,527 \mathrm{f}$ & $56 \mathrm{fg}$ \\
$\mathbf{1 0 0 \%}$ NPK & $61,045 \mathrm{a}$ & $37,290 \mathrm{a}$ & $47,545 \mathrm{a}$ & $78 \mathrm{ab}$ \\
MR & $35,084 \mathrm{e}$ & $11,237 \mathrm{~h}$ & $21,377 \mathrm{ef}$ & $52 \mathrm{~g}$ \\
MR + 100\% PK & $46,672 \mathrm{~d}$ & $20,217 \mathrm{e}$ & $30,037 \mathrm{~d}$ & $67 \mathrm{e}$ \\
MR + 100\% RPM & $47,227 \mathrm{~cd}$ & $20,890 \mathrm{e}$ & $30,850 \mathrm{~d}$ & $68 \mathrm{e}$ \\
MR + 50\% RPM + 50\% PK & $45,203 \mathrm{~d}$ & $23,893 \mathrm{~d}$ & $34,042 \mathrm{c}$ & $70 \mathrm{de}$ \\
SR & $44,972 \mathrm{~d}$ & $17,173 \mathrm{f}$ & $28,528 \mathrm{~d}$ & $60 \mathrm{f}$ \\
SR + 100\% PK & $61,867 \mathrm{a}$ & $36,500 \mathrm{a}$ & $44,550 \mathrm{a}$ & $82 \mathrm{a}$ \\
SR + 100 \% RPM & $50,316 \mathrm{bcd}$ & $27,160 \mathrm{c}$ & $37,280 \mathrm{~b}$ & $73 \mathrm{dc}$ \\
SR + 50\% RPM + 50\% PK & $62,517 \mathrm{a}$ & $37,010 \mathrm{a}$ & $45,873 \mathrm{a}$ & $81 \mathrm{ab}$ \\
MSR & $44,289 \mathrm{~d}$ & $14,020 \mathrm{~g}$ & $24,122 \mathrm{e}$ & $58 \mathrm{f}$ \\
MSR + 100\% PK & $55,604 \mathrm{abc}$ & $29,620 \mathrm{~b}$ & $38,958 \mathrm{~b}$ & $76 \mathrm{bc}$ \\
MSR + 100 \% RPM & $51,905 \mathrm{bcd}$ & $24,943 \mathrm{~d}$ & $36,050 \mathrm{bc}$ & $69 \mathrm{de}$ \\
MSR + 50\% RPM + 50\% PK & $56,551 \mathrm{ab}$ & $29,377 \mathrm{~b}$ & $38,612 \mathrm{~b}$ & $76 \mathrm{bc}$ \\
\hline
\end{tabular}

Means in the same column followed by the same letters are not significantly different (DMRT 0.05), $\mathrm{MC}=$ marketable cobs, $\mathrm{GCY}=$ green cob yield, $\mathrm{BY}=$ biomass yield, $\mathrm{HI}=$ harvest index, $\mathrm{MR}=$ maize residue, $\mathrm{SR}=$ soybean residue, $\mathrm{MSR}=$ maize + soybean residue, $\mathrm{RPM}=$ residual poultry manure, $\mathrm{PM}=$ poultry manure, $\mathrm{PK}=$ phosphorus and potassium fertilizer 
Table 6 . Pearson linear correlation coefficients between green cob yield and yield component as affected by organic and inorganic fertilizer

\begin{tabular}{|c|c|c|c|c|c|c|c|c|}
\hline & GCY & PH & CL & $\mathbf{C W}$ & NKPP & TGW & BY & HI \\
\hline GCY & 1 & & & & & & & \\
\hline PH & $0.95 * * *$ & 1 & & & & & & \\
\hline CL & $0.94 * * *$ & $0.90 * * *$ & 1 & & & & & \\
\hline $\mathbf{C W}$ & $0.99 * * *$ & $0.92 * * *$ & $0.97 * * *$ & 1 & & & & \\
\hline NKPP & $0.97 * * *$ & $0.94 * * *$ & $0.98 * * *$ & $0.98 * * *$ & 1 & & & \\
\hline TGW & $0.99 * * *$ & $0.95 * * *$ & $0.94 * * *$ & $0.98 * * *$ & $0.98 * * *$ & 1 & & \\
\hline BY & $0.99 * * *$ & $0.96 * * *$ & $0.94 * * *$ & $0.99 * * *$ & $0.97 * * *$ & $0.98 * * *$ & 1 & \\
\hline HI & $0.98 * * *$ & $0.94 * * *$ & $0.89 * * *$ & $0.95 * * *$ & $0.93 * * *$ & $0.97 * * *$ & $0.97 * * *$ & 1 \\
\hline
\end{tabular}

$*, * *, * * *$ significant level at $\mathrm{P}<0.05,0.001,0.0001, \mathrm{GCY}=$ green cob yield, $\mathrm{PH}=$ plant height, $\mathrm{CL}=\mathrm{cob}$ length, $\mathrm{GCW}=$ green cob weight, NKPC $=$ number of kernels per cob, TGW = thousand grain weight, $\mathrm{BY}=$ biomass yield, $\mathrm{HI}=$ harvest index

Table 7. Effects of organic manure residues and inorganic fertilizer on soil chemical properties

\begin{tabular}{|c|c|c|c|c|c|c|c|}
\hline Treatment & pH & OM (\%) & TN (\%) & $\begin{array}{l}\mathrm{S} \\
(\mathrm{mg} / \mathrm{kg})\end{array}$ & $\begin{array}{l}\text { Av. P } \\
\text { (mg/kg) }\end{array}$ & $\begin{array}{l}\text { Ex.K } \\
(\mathrm{cmolc} / \mathrm{kg})\end{array}$ & $\begin{array}{l}\text { CEC } \\
(\mathrm{cmolc} / \mathrm{kg})\end{array}$ \\
\hline Control & $4.73 \mathrm{e}$ & $1.84 \mathrm{~h}$ & $0.06 \mathrm{~h}$ & $36.7 \mathrm{~d}$ & $13.7 \mathrm{i}$ & $0.15 \mathrm{e}$ & $13.9 \mathrm{~h}$ \\
\hline $100 \%$ NPK & $4.86 \mathrm{e}$ & $1.94 \mathrm{~h}$ & $0.08 \mathrm{gh}$ & $51.2 \mathrm{~d}$ & $15.0 \mathrm{i}$ & $0.16 \mathrm{e}$ & $15.9 \mathrm{~h}$ \\
\hline MR & $5.82 \mathrm{~cd}$ & $2.75 \mathrm{fg}$ & $0.10 \mathrm{fg}$ & $74.7 \mathrm{a}$ & $20.4 \mathrm{~h}$ & $0.31 \mathrm{~d}$ & $18.9 \mathrm{ef}$ \\
\hline MR + 100\% PK & $5.54 \mathrm{~d}$ & $2.93 \mathrm{efg}$ & $0.11 \mathrm{fg}$ & $76.2 \mathrm{abc}$ & $26.3 \mathrm{gf}$ & $0.44 \mathrm{c}$ & $21.1 \mathrm{cde}$ \\
\hline MR $+100 \%$ RPM & $6.72 \mathrm{a}$ & $4.62 \mathrm{a}$ & $0.24 a b c$ & $83.2 \mathrm{abc}$ & $35.7 \mathrm{abc}$ & $0.58 \mathrm{ab}$ & $29.1 \mathrm{a}$ \\
\hline \multicolumn{8}{|l|}{ MR $+50 \%$ RPM $+50 \%$} \\
\hline PK & $6.34 \mathrm{ab}$ & $3.75 \mathrm{~cd}$ & $0.19 \mathrm{e}$ & $75.2 \mathrm{abc}$ & $31.8 \mathrm{~cd}$ & $0.50 \mathrm{bc}$ & 21.6bcde \\
\hline SR & $5.58 \mathrm{~cd}$ & $2.74 \mathrm{fg}$ & $0.22 \mathrm{cde}$ & $68.2 \mathrm{bcd}$ & $23.67 \mathrm{gh}$ & $0.29 \mathrm{~d}$ & 20.4def \\
\hline $\mathrm{SR}+100 \% \mathrm{PK}$ & $5.83 \mathrm{~cd}$ & $2.58 \mathrm{~g}$ & $0.20 \mathrm{de}$ & $59.5 \mathrm{bcd}$ & $27.0 \mathrm{efg}$ & $0.47 \mathrm{c}$ & $23.5 \mathrm{bcd}$ \\
\hline SR + $100 \%$ RPM & $6.79 \mathrm{a}$ & $4.57 \mathrm{ab}$ & $0.27 \mathrm{a}$ & $81.4 \mathrm{abc}$ & $38.1 \mathrm{a}$ & $0.59 \mathrm{a}$ & $30.4 \mathrm{a}$ \\
\hline \multicolumn{8}{|l|}{$\mathrm{SR}+50 \%$ RPM a $50 \%$} \\
\hline PK & $6.45 \mathrm{ab}$ & $3.96 \mathrm{bcd}$ & $0.24 b c$ & $72.0 \mathrm{abc}$ & $30.6 \mathrm{de}$ & $0.51 b c$ & $28.5 \mathrm{a}$ \\
\hline MSR & $5.73 \mathrm{~cd}$ & $3.33 \mathrm{edf}$ & $0.12 f$ & $100.2 \mathrm{a}$ & $20.2 \mathrm{~h}$ & $0.33 \mathrm{~d}$ & $17.4 \mathrm{f}$ \\
\hline MSR $+100 \%$ PK & $5.62 \mathrm{~cd}$ & $3.49 \mathrm{de}$ & $0.19 \mathrm{de}$ & $78.0 \mathrm{abc}$ & 29.9def & $0.48 \mathrm{c}$ & $24.0 \mathrm{bc}$ \\
\hline MSR + $100 \%$ RPM & $6.69 \mathrm{a}$ & $4.89 \mathrm{a}$ & $0.25 \mathrm{a}$ & $95.2 \mathrm{a}$ & $37.2 \mathrm{ab}$ & $0.64 \mathrm{a}$ & $29.9 a$ \\
\hline MSR $+50 \%$ RPM $+50 \%$ & & & & & & & \\
\hline PK & $6.03 \mathrm{bc}$ & $4.26 \mathrm{abc}$ & $0.22 \mathrm{~cd}$ & $79.6 \mathrm{abc}$ & $33.4 \mathrm{bcd}$ & $0.51 b c$ & $24.7 \mathrm{~b}$ \\
\hline
\end{tabular}

Means in the same column followed by the same letters are not significantly different (DMRT 0.05 ), MR= maize residue, $\mathrm{SR}=$ soybean residue, $\mathrm{MSR}=$ maize + soybean residue, $\mathrm{RPM}=$ residual poultry manure, $\mathrm{PM}=$ poultry manure, $\mathrm{PK}=$ phosphorus and potassium fertilizer, Av. $\mathrm{P}=$ available $\mathrm{P}, \mathrm{Ex} . \mathrm{K}=$ exchangeable $\mathrm{K}$ 